\section{Christmas quiz}

1. Who says we should harness eccentric buoys?

2. What is the next number in the series $1,2,3,5,8,13$, $21,34,55 \ldots$ and in what way is this series linked both to Pisa and to leaves?

3. What professor of chemistry wrote an opera whose most famous tune was, many years later, used in the musical 'Kismet'?

4. She wanted his next book dedicated to her and indeed it was-but instead of being a story of wide popular acclaim, it was an elementary treatise on determinants. Who was she?

5. Who has an answer to Logical Positivism in the 'family Four Position Base'?

6. Appearing twice a year, they are common in India, China and Japan but are probably indigenous to western Asia. In ancient Egypt one variety was accorded some degree of divinity and is featured on monuments of that period. If you had one what would you do with it?

7. He studied in Vienna and by the age of 26 had become Professor of Mathematics at Gratz University. Four years later he moved to the Chair of Physics in Vienna, and it is as a physicist and psychologist that he is remembered most. Towards the end of his life he became a member of the Austrian house of Peers. The rather one sided view from one of his philosophical works was featured briefly in a recent edition of Nature; what was it and who was he?

8. What was the concept that was first suggested publicly in an address in Frankfurt am Main in January 1912; and who delivered the address?

9. Where and when did the largest single oil spill occur?

10. What is the most commonly used tricyclic antidepressant and what are the main effects of such compounds?

11. What is dendrochronology and what importance does it have in art?

12. Of what biochemicals are these the empirical formulae: (a) $\mathrm{C}_{35} \mathrm{H}_{28} \mathrm{MgN}_{4} \mathrm{O}_{5}$; (c) $\mathrm{C}_{31} \mathrm{H}_{32} \mathrm{ClFeN}_{4} \mathrm{O}_{4}$ ?

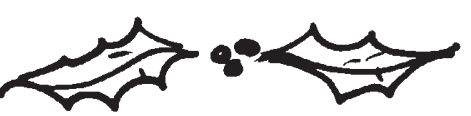

13. Name the group which in 1974 officially wanted restriction restricted?

14. By what discovery in 1974 was St Bartholomew's Hospital specifically linked to a gene deletion?

15. Which enzymes are deficient in: (a) Fabrys disease; (b) Sandhoffs disease; (c) Pompes disease?

16. Who saw fruit in a padded cell?

17. From where, precisely, was Marconi's first transatlantic radio transmission made?

18. How many optical telescopes bigger than 100 inches are in operation or under construction in the Southern Hemisphere and where are they?

19. Some useful quotations for authors to know-but who said them first?

(a) Accuse not Nature, she hath done her pant ...

(b) can't be Nature ... not sense ...

(c) except the blind forces of Nature, nothing moves in this world ...

(d) The fault was Nature's fault not thine ...

(e) What's a' the jargon of your schools; Your Latin names for horns and stools;

If honest Nature made you fools.

(f) Thrice happy he who not mistook Hath read in Nature's mystic book ...

(g) to be constant, in Nature were inconstancy ...

(h) Nature is always wise in every part ...

(i) Nature abhors imperfect work ...

(j) But in them Nature's copy not eterne . . .

(k) Nature knows a thing or two ...

20. Who wrote:

Nature and Nature's laws lay hid in night:

God said let Newton be! and all was light

and who replied with what?

21. For what work did the following win Nobel Prizes: D. Bovet (1957); J. Heyrovsky (1959); G. von Bekesy (1961); G. Wilkinson (1973)?

See page 622 for answers.

\title{
Spinning into space?
}

RECENT publicity about possible 'antigravity' devices which seem to defy Newton with the aid of a spinning top or two encourages us to offer for seasonable speculation the following question, taken from the 1969 Christmas Examination for Junior and Senior Honours in the Natural Philosophy Department of the University of Aberdeen. There is no prize for any correct answer, and no answer is presented in the pages of this issue of Nature.

"There is currently an application for a patent for an antigravity device based on the following argument:

'A particle at the Earth's surface has a critical horizontal velocity $v$ such that this velocity will cause it to orbit the Earth in a circle. If this velocity is exceeded, the particle will tend into an orbit at a greater mean distance from the Earth's centre. The actual direction of the velocity in a horizontal plane makes no difference to the foregoing conclusion. Now such a horizontal velocity can in principle be achieved by spinning two particles joined by a horizontal bar as in a dumbell. Each particle can thus be

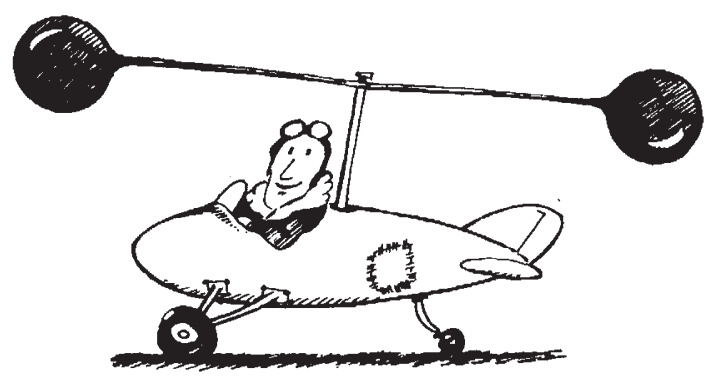

made to have a velocity $V$ which is greater than $v$, and so they should jointly rise. The proposed method of defying gravity therefore consists in spinning a dumbell fast enough.'

What is the flaw in the argument, and how would you try to persuade the inventor (an imaginative engineer who might not be convinced by an argument based on the motion of a common centre of gravity) that he would be foolish to waste money on pursuing the patent?" 